\title{
Analysis and Design of Single Switch Hybrid Step-Up Converter
}

\author{
Ravivarman Shanmugasundaram ${ }^{1}$, Jeyabharath Rajaiah², Veena Parasunath ${ }^{2}$ \\ ${ }^{1}$ Department of EEE, K. S. Rangasamy College of Technology, Tamilnadu, India \\ ${ }^{2}$ Department of EEE, KSR Institute for Engineering and Technology, Tamilnadu, India \\ Email: *ravivarman@ksrct.ac.in
}

Received 29 February 2016; accepted 16 April 2016; published 19 April 2016

Copyright (C) 2016 by authors and Scientific Research Publishing Inc.

This work is licensed under the Creative Commons Attribution International License (CC BY). http://creativecommons.org/licenses/by/4.0/

(c) (i) Open Access

\begin{abstract}
A Single Switch Hybrid Step-up Converter with high voltage gain, which is suitable for renewable energy system, is proposed in this paper. The proposed converter consists of one switched diodeinductor cell and a capacitor. While switching, both are charged in parallel from the input source and discharged in series to the output. In order to obtain extra voltage gain at lower duty cycle, the voltage multiplier cell is integrated with the proposed converter. The main advantages of the converter are high voltage gain, reduced voltage stress, simple structure and low output voltage ripples. The operating principle and steady state theoretical analysis are presented. A $250 \mathrm{~W}$ prototype converter is implemented with $12 \mathrm{~V}$ input and $120 \mathrm{~V}$ output to verify the design and analysis of this converter and it has an efficiency of over $90 \%$ in all operations.
\end{abstract}

\section{Keywords}

DC-DC Power Conversion, Switched-Inductor, Step-Up Converter, Voltage Multiplier

\section{Introduction}

A hefty and viable economic growth in India is engaging a great demand for energy resources. There is a risk of growing in import of oil and coal in future, which leads to an increase in problems for energy security. In India, a large proportion of people still live without access to electricity and other forms of commercial energy. More than $50 \%$ of the population in India has little or no energy for life and living. In order to overcome the above said problems, development of renewable energy sources is a good solution. The power generation through photovoltaic panels, and fuel cells bring advantages like diversification of energy sources, increased distributed generation and also supplies electrical energy to isolated areas [1]. Various applications such as uninterrupted

${ }^{*}$ Corresponding author. 
power supply and motor drives, often require a DC bus voltage of 200 or $400 \mathrm{~V}$. Unfortunately, the voltage obtained from solar panels, fuel cells, small wind generators, and others are low [2].

A huge number of DC-DC converter topologies were proposed and implemented in the range of hundred watt to multiples of $\mathrm{kW}$. The DC-DC converters are generally classified in to two-isolated converters and nonisolated converters. Isolated converter topologies have disadvantages like increased volume and decreased efficiency. Due to this, the non-isolated converter topologies seem to be better choices for converting the low voltage to high voltage [3]-[5]. In non-isolated DC-DC boost converters, the low voltage is stepped-up by cascading two or more boost converters, incorporating switched capacitor (SC) and/or switched inductor (SL) network with boost converter, boost converter with coupled-inductor and integrating the combination of these four with a boost converter.

In cascaded topology, two or more converters are cascaded together, in which the energy is transferred from one stage to another stage to obtain a high voltage gain. Hence their conduction loss is high and it requires large number of components [6]-[8]. To increase the voltage gain of the converter, the capacitors or inductors are switched and it will act as a charge pump. The main advantage of the switched capacitor based boost converter is that there is no need of transformer or inductors [9] [10]. The main drawbacks of this topology are complex topology, high cost, low power level and high pulsating current in the input side will shorten the life of PV cell. In switched inductor based boost converter, the voltage stress across the main active switch is high which leads to high conduction loss [11].

In order to reduce the voltage and current stress in the switch, the coupled inductor based topology has been proposed [12]-[14]. The voltage gain can be increased by increasing the turns ratio of the coupled-inductor which is large in size. But the RMS current through the active switch is high. A circuit that combines the switched-capacitor and coupled-inductor methods with boost converter is proposed to achieve high voltage gain [15]-[18]. The leakage inductance of the coupled inductor is used to reduce the switching constraints. The drawback of these converters is hard switching which reduces the power rating of the converter. The voltage gain can be increased additionally by combining voltage multiplier cell with the coupled-inductor boost converter and switched-capacitor boost converter [5] [19] [20].

At the moment, there are large numbers of converter topologies and it is a difficult task to choose the best one for the renewable energy applications. The major problems in the selection of non-isolated converters are cost, voltage and current stresses and efficiency. The voltage gain of the converter must be large enough even in small duty cycle. In this paper, an alternative method to achieve high voltage gain DC-DC converter is presented. The operation with switching waveforms, the design considerations, simulated and experimental results are presented in the upcoming sections.

\section{Operating Modes and Steady State Analysis}

Figure 1 shows the topology of the proposed DC-DC converter which consists of SL cell, switched-capacitor and voltage multiplier (VM) cell, called Single Switch Hybrid Switched Diode Inductor-Capacitor (HSDI-C) Converter. The SL cell is formed by two inductors, $L_{S 1}=L_{S 2}=L_{S}$ and three diodes. During on-time, the two inductors are charged in parallel with the supply and during off-time, the same two inductors will discharge their energy in series. The SC cell is formed by capacitor $C$. When the switch is ON, the capacitor either charges or discharges. At that moment the capacitor current will increase to a high value. To limit the current rise, an

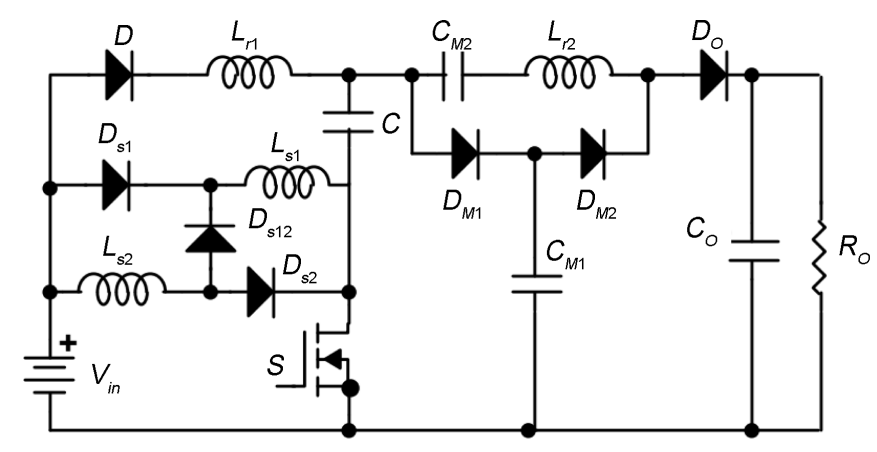

Figure 1. Circuit configuration of the proposed converter. 
inductor may be introduced in series with the capacitor. This inductor and capacitor will form a tank circuit and it resonates at a frequency,

$$
f_{O}=1 / 2 \pi \sqrt{L_{r 1} C} .
$$

We have to ensure that the inductor current has to reach zero before the switch is turned off. The inductor value has to be properly selected from the equation of resonant frequency. If the $L_{S 1}, L_{S 2}$ and $C$ are very large, then the voltage across capacitor and current through the inductor will be constant. Figure 2 and Figure 3 show the circuit operating modes and its corresponding waveforms. The following assumptions are made to analyze the circuit: All the components in the converter are ideal; inductors are conducting continuously; the output filter capacitor is large enough to obtain a ripple free output voltage.

\subsection{Mode I $\left(t_{0}-t_{1}\right)$}

In this mode, the switch is turned off. Once it is turned off, the diodes $D_{M 1}, D_{S 12}$ and $D_{O}$ are forward biased and diodes $D, D_{M 2}, D_{S 1}$ and $D_{S 2}$ are reverse biased. The capacitor $C$, the inductors $L_{S 1}$ and $L_{S 2}$ are connected in series with the input source as shown in Figure 2(a). The previously stored energy is discharged to $C_{M 1}$ through $D_{M 1}$, to capacitor $C_{M 2}$ through $L_{r 2}$ and to output capacitor $C_{O}$ through $D_{O}$. The current in the resonant inductor $L_{r 2}\left(i_{L r 2}\right)$ is increased linearly up to the level of SL cell current and simultaneously the current in the diode $D_{M 1}$ is reduced linearly. The current $i_{L r 2}$ is expressed by (2). The voltage across capacitor $C_{M 1}$ is increased and across $C_{M 2}$ is decreased at same rate, hence the voltage across $L_{r 2}$ is constant in this mode. The equation for capacitor voltages are given in (3) and (4).

$$
\begin{gathered}
i_{L r 2}(t)=\frac{V_{C M 1}\left(t_{4}\right)+V_{C M 2}\left(t_{4}\right)-V_{O}}{L_{r 2}} t \\
V_{C M 1}(t)=V_{C M 1}\left(t_{4}\right)+\left(\frac{i_{L S}\left(t_{0}\right) \cdot t-\frac{\left(V_{C M 1}\left(t_{4}\right)+V_{C M 2}\left(t_{4}\right)-V_{O}\right) t^{2}}{2 L_{r 2}}}{C_{M 1}}\right)
\end{gathered}
$$

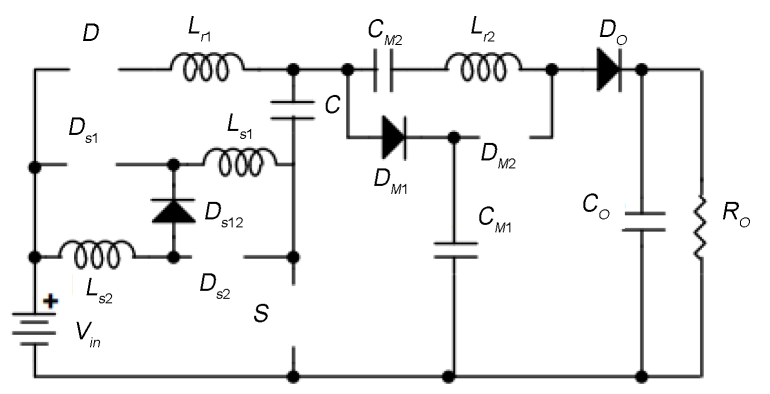

(a)

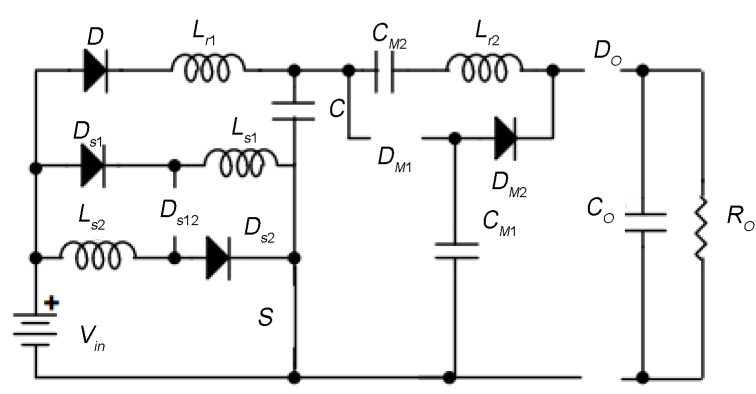

(c)

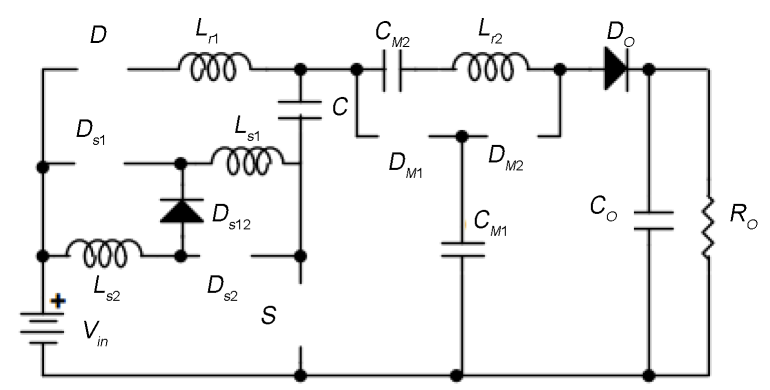

(b)

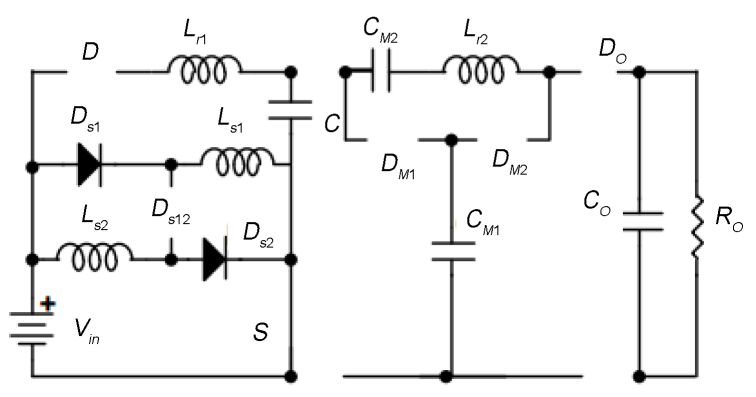

(d)

Figure 2. Operating modes of the proposed converter (a) Mode I, (b) Mode II, (c) Mode III, (d) Mode IV. 


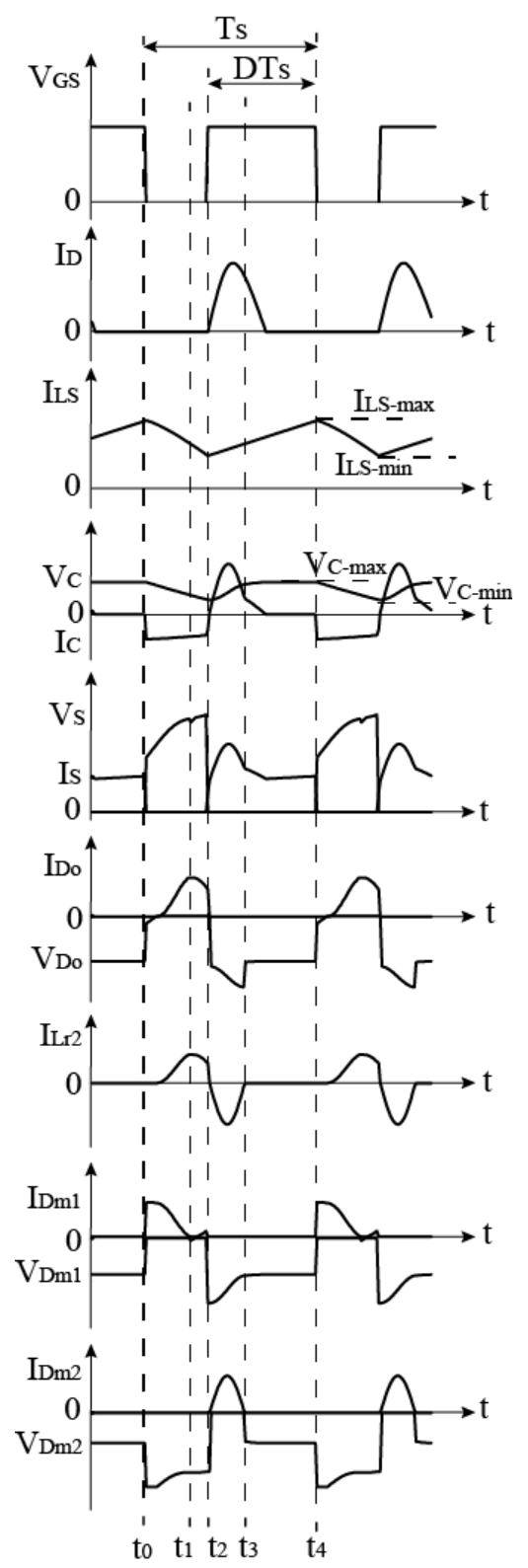

Figure 3. Ideal waveforms of the proposed converter.

$$
V_{C M 2}(t)=V_{C M 2}\left(t_{4}\right)-\left(\frac{\frac{\left(V_{C M 1}\left(t_{4}\right)+V_{C M 2}\left(t_{4}\right)-V_{O}\right) t^{2}}{2 L_{r 2}}}{C_{M 2}}\right)
$$

\subsection{Mode II $\left(t_{1}-t_{2}\right)$}

At the instant $t_{1}$, the diode current $i_{\mathrm{DM} 1}$ is zero and the current $i_{\mathrm{Lr} 2}$ and switched inductor cell current are equal as shown in Figure 2(b) and Figure 3 and it is expressed in (5). Then the energy stored in the switched inductor cell is transmitted to load though the output diode $D_{O}$.

$$
i_{L r 2}(t)=i_{L S}(t)
$$




$$
\begin{gathered}
V_{C M 1}(t)=V_{C M 1}\left(t_{1}\right) \\
V_{C M 2}(t)=V_{C M 2}\left(t_{1}\right)-\frac{i_{L S}\left(t_{1}\right) \cdot t}{C_{M 2}}
\end{gathered}
$$

In both the modes, the current flowing through $C$ and $L_{S 1}$ are same and it is expressed as

$$
i_{L S}=-i_{C}=i_{L S-\max }-\frac{V_{O}-V_{I N}-V_{C}}{L_{S}}\left(t-t_{0}\right)
$$

From the assumptions made earlier, the switching frequency must satisfy the condition $T_{S} \ll 2 \pi \sqrt{L_{S} C}$. The capacitor voltage $V_{C}$ and the switched inductor cell current can be expressed approximately as in (9) and (10).

$$
\begin{gathered}
V_{C} \simeq V_{C-\max }-\frac{I_{O}}{(1-D) C}\left(t-t_{0}\right) \\
i_{L S}=-i_{C} \simeq i_{L S-\max }-\frac{V_{O}-2 V_{I N}}{L_{S}}\left(t-t_{0}\right)
\end{gathered}
$$

At the instant $t_{2}$, the inductor current and the capacitor voltage both decrease and they are expressed as

$$
\begin{gathered}
i_{L S-\min }=i_{L S-\max }-\frac{V_{O}-2 V_{I N}}{L_{S}}(1-D) T_{S} \\
V_{C-\text { min }}=V_{C-\text { max }}-\frac{I_{O}}{C} T_{S}
\end{gathered}
$$

\subsection{Mode III $\left(t_{2}-t_{3}\right)$}

The switch is turned on at the instant, $t_{2}$. The diodes $D_{S 12}, D_{M 1}$ and $D_{O}$ are reverse biased; $D_{S 1}, D_{S 2}, D_{M 2}$ and $D$ are forward biased as shown in Figure 2(c). The switched inductor cell and the capacitor $C$ form the tank circuit. The supply voltage appears across the tank circuit will cause a sinusoidal resonant current in $C$. The switched inductor cell current will increase as shown in Figure 3. The $i_{L S}$, $i_{C}$ and $V_{C}$ can be expressed exactly as follows.

$$
\begin{gathered}
i_{C}=I_{C} \sin \omega_{0}\left(t-t_{2}\right) \\
V_{C}=V_{I N}-\frac{\Delta V_{C}}{2} \cos \omega_{0}\left(t-t_{2}\right) \\
i_{L S}=I_{L S \text {-min }}+\frac{V_{I N}}{L_{S}}\left(t-t_{2}\right)
\end{gathered}
$$

where $i_{C}$ and $V_{C}$ are the amplitudes of the oscillation and $I_{L S \text {-min }}$ is the minimum SL cell current. Once the current oscillation amplitude reaches zero, the diode $D$ is reverse biased. At $t_{3}$, the capacitor reaches to the maximum voltage, i.e.,

$$
V_{C-\max }=V_{I N}+\frac{\Delta V_{C}}{2}
$$

Since the output diode $D_{O}$ is reverse biased, the energy stored in the $C_{M 1}$ is transferred to $C_{M 2}$ through $D_{M 2}$ until the time instant $t_{3}$. At the instant $t_{3}$, the diode $D_{M 2}$ is reverse biased, because the energy is fully transferred from $C_{M 1}$ to $C_{M 2}$. In this mode the equations for $i_{L r 2}, V_{C M 1}$ and $V_{C M 2}$ are given in (17), (18) and (19).

$$
\begin{gathered}
i_{L r 2}=\frac{\left(V_{C M 1}\left(t_{2}\right)-V_{C M 2}\left(t_{2}\right)\right) \cdot \sin \left(\omega_{0} \cdot t\right)}{\sqrt{L_{r 2} / C_{e q}}} \\
C_{e q}=\frac{C_{M 1} \cdot C_{M 2}}{C_{M 1}+C_{M 2}} \\
\omega_{0}=1 / \sqrt{L_{r 2} C_{e q}}
\end{gathered}
$$




$$
\begin{aligned}
& V_{C M 1}(t)=V_{C M 1}\left(t_{2}\right)-\left(V_{C M 1}\left(t_{2}\right)-V_{C M 2}(t)\right) \cdot \cos \left(\omega_{0} t\right) \\
& V_{C M 2}(t)=V_{C M 2}\left(t_{2}\right)-\left(V_{C M 1}\left(t_{2}\right)-V_{C M 2}(t)\right) \cdot \cos \left(\omega_{0} t\right)
\end{aligned}
$$

The average output voltage will appear across the output capacitor $C_{O}$ and it will be the sum of the voltages across the input of multiplier cell and the capacitor $C_{M 2}$.

\subsection{Mode IV $\left(t_{3}-t_{4}\right)$}

Once the resonance condition stops in the SL cell, the main switch S continues to conduct. So the SL cell current increases further linearly as specified by the Equation (15) and it maximum value is given in the Equation (20). Since the capacitor voltage is at maximum constant value, there will be no current flowing through it.

$$
I_{L S-\max }=I_{L S-\min }+\frac{V_{I N}}{L_{S}} D T_{S}
$$

Similarly, at $t_{3}$, the current in the resonant inductor $L_{r 2}$ is zero and in turn it reverse biases the diode $D_{M 2}$. Since the output circuit is completely isolated from the source as shown in Figure 2(d), the SL cell will store energy. The SL cell and SC cell will remain in this state until the switch is turned off.

$$
\begin{gathered}
i_{L r 2}(t)=0 \\
V_{C M 1}(t)=V_{C M 1}\left(t_{3}\right) \\
V_{C M 2}(t)=V_{C M 2}\left(t_{3}\right)
\end{gathered}
$$

Once the switch is turned off, the above four modes will be repeated.

\section{Design Considerations}

By using volt-second balance theory in the SL cell, the equation for output voltage can be given as

$$
V_{O}=\frac{3+D}{1-D} V_{I N}
$$

where $D$ is the duty ratio of the switch $S, V_{I N}$ is the input voltage and $V_{O}$ is the output voltage of the converter. The resonance occurs in the capacitor $C$ during its charging process. The oscillation of capacitor voltage plays a vital role in the selection of parameters of the tank circuit. In the capacitor, the energy stored is equal to the energy supplied to the load. Therefore,

$$
\left(V_{C-\max }-V_{C-\min }\right) C=I_{O} T_{S}
$$

The capacitor will charge according to the resonant frequency of the tank circuit. So it can be expressed as

$$
\left(V_{C-\max }-V_{C-\min }\right) C=2 I_{C} \sqrt{L_{r 1} C}
$$

From (25) and (26), the amplitudes of current and voltage oscillations are given as

$$
\begin{gathered}
I_{C}=\frac{I_{O} T_{S}}{2 \sqrt{L_{r 1} C}} \\
\Delta V_{C}=V_{C-\max }-V_{C-\min }=\frac{I_{O} T_{S}}{C}
\end{gathered}
$$

During the discharge process of SL cell, the charge flowing through it is equal to charge flowing out from capacitor $C$. The ripple current of SL cell is given by

$$
\Delta I_{L S}=\frac{V_{I N}}{L_{S}} d T_{S}
$$

According to the condition said earlier, the on time of the switch must be longer than that of the resonant period and it is given in the Equation (30). 


$$
f_{0}=\frac{1}{2 \pi \sqrt{L_{r 1} C}}>\frac{1}{2 D T_{S}}
$$

Thus the value of capacitor $C$, switched inductor $L_{S 1}=L_{S 2}$ and resonant inductor $L_{r 1}$ are determined by using the Equations (28), (29) and (30). The capacitance value of the capacitor $C_{M 1}$ depends upon the maximum output power $P_{O \max }$, output voltage and switching frequency and it is given in Equation (31).

$$
C_{M 1} \geq \frac{P_{O \max } \cdot T_{S}}{V_{C M 1}^{2}}
$$

The resonance inductor $L_{r 2}$ can be determined according to the maximum current variation through it and it is defined by

$$
\frac{\mathrm{d} i}{\mathrm{~d} t}=\frac{V_{O}-V_{C M 2}}{L_{r 2}}
$$

Table 1 shows comparison of the ideal voltage gain and ideal voltage stress of switch and diodes of the proposed converter and other high step-up boost converters. It can be noticed clearly that the proposed topology has high gain for the same duty ratio but the voltage stress on diode and switch is same. The converter proposed by [21] has less voltage stress on switch and diode, but its dc gain is also less compared to proposed converter.

\section{Simulation and Experimental Results}

From the design considerations and specifications, the component parameters are calculated and it is presented in Table 2. The proposed converter is modelled and simulated using PSIM v9.0. The input supply is kept at 12 $\mathrm{V}$ and the switch is operated at $100 \mathrm{kHz}$ switching frequency with duty ratio 0.64 , the output voltage is $120 \mathrm{~V}$.

The simulation waveforms are as shown in Figure 4 and it resembles the waveforms obtained in the theoretical analysis. To validate the performance of proposed converter, a prototype has been implemented and tested experimentally according to the parameters presented in Table 2.

Figure 5(a) shows the experimental waveforms of $V_{I N}$, input current $I_{I N}$, output voltage $V_{O}$ and output current $I_{O}$. At full-load $120 \mathrm{~W}$, the output voltage is $119 \mathrm{~V}$ and the currents are measured using a shunt resistor of $2 \Omega$, therefore, the measured load current is $0.99 \mathrm{~A}$ and the input current is $11.65 \mathrm{~A}$. Figure 5(b) shows the gate voltage $V_{G S}$, voltage stress across switch $V_{D S}$ of $67.8 \mathrm{~V}$, current through the switch $I_{D S}$ and the voltage across the multiplier capacitor $C_{m 1}$ of $60 \mathrm{~V}$. The current through the SL cell, diode $D$, the capacitor $C$ and the resonant inductor are shown in Figure 5(c).

The comparison between the simulation and experimental values of various parameters are given in Table 3. Because of the approximation and ideal conditions, the difference between the simulation and experimental value exists. However, the difference between those two are small. Hence the theoretical, simulation and experimental analysis are validated. The efficiency of the proposed converter has been measured at fixed duty ratio $(D=$ $0.64)$ for various input voltages $\left(V_{I N}=12 \mathrm{~V}, V_{I N}=24 \mathrm{~V}\right.$ and $\left.V_{I N}=36 \mathrm{~V}\right)$ and it is shown in Figure 6.

From the characteristics, it is found that the conversion efficiency is more than $90 \%$ and it can be better when

\begin{tabular}{|c|c|c|c|c|c|}
\hline \multirow[b]{2}{*}{ Parameters } & \multicolumn{5}{|c|}{ Converters } \\
\hline & $\begin{array}{l}\text { Proposed } \\
\text { Converter }\end{array}$ & $\begin{array}{c}\text { Converter } \\
{[22]}\end{array}$ & $\begin{array}{c}\text { Converter } \\
{[19]}\end{array}$ & $\begin{array}{c}\text { Converter } \\
\text { [23] }\end{array}$ & $\begin{array}{c}\text { Converter } \\
{[21]}\end{array}$ \\
\hline \multirow{2}{*}{ dc gain } & $3+D$ & 2 & 2 & $1+2 D$ & $3-D$ \\
\hline & $\overline{1-D}$ & $\overline{1-D}$ & $\overline{1-D}$ & $\overline{1-D}$ & $\overline{1-D}$ \\
\hline \multirow{2}{*}{ Voltage stress on switch } & $V_{o}$ & $V_{o}$ & $V_{o}$ & \multirow{2}{*}{$V_{o}$} & $V_{o}$ \\
\hline & $\overline{2}$ & $\overline{2}$ & $\overline{2}$ & & $\overline{3-D}$ \\
\hline \multirow{2}{*}{$\begin{array}{l}\text { Voltage stress on } \\
\text { output diode }\end{array}$} & $V_{o}$ & $V_{o}$ & $V_{o}$ & \multirow{2}{*}{$V_{o}$} & $V_{o}$ \\
\hline & $\overline{2}$ & $\overline{2}$ & $\overline{2}$ & & $\overline{3-D}$ \\
\hline
\end{tabular}
the input voltage is large. Figure 7 shows the comparison of output voltage variation of the proposed converter,

Table 1. Comparison of proposed converter and other converters. 
Table 2. Design specifications and components used in the prototye model.

\begin{tabular}{cc}
\hline Parameters & Values \\
\hline Input voltage, $V_{I N}$ & $12 \mathrm{~V}$ \\
Output voltage, $V_{O}$ & $120 \mathrm{~V}$ \\
Output power, $P_{O}$ & $500 \mathrm{~W}$ \\
Switching frequency, $f_{s}$ & $100 \mathrm{kHz}$ \\
C (Polypropylene) & $4.7 \mu \mathrm{F}$ \\
$L_{S 1}$ and $L_{S 2}$ & $40 \mu \mathrm{H}$ \\
$L_{r 1}$ (air core) & $0.5 \mu \mathrm{H}$ \\
$C_{M 1}$ and $C_{M 2}$ (Polypropylene) & $1 \mu \mathrm{F}$ \\
$L_{r 2}$ & $1 \mu \mathrm{H}$ \\
$C_{O}$ (Electrolytic) & $100 \mu \mathrm{F}$ \\
$D, D_{S 1}, D_{S 2}, D_{S 12}, D_{M 1}, D_{M 2}$ and $D_{O}$ & MBR20200 \\
$\mathrm{S}$ (N Channel MOSFET) & IRF250 \\
\hline
\end{tabular}

Table 3. Comparison between simulated and experimental value of various parameters.

\begin{tabular}{ccc}
\hline Parameters & Simulation & Experiment \\
\hline Output voltage, $V_{o}$ & $120 \mathrm{~V}$ & $119 \mathrm{~V}$ \\
Output current, $I_{o}$ & $2.08 \mathrm{~A}$ & $2.1 \mathrm{~A}$ \\
Input current $I_{I N}$ & $20.8 \mathrm{~A}$ & $21.9 \mathrm{~A}$ \\
Average $V_{C m 1}$ & $60 \mathrm{~V}$ & $59.8 \mathrm{~V}$ \\
Voltage stress across switch, $V_{D S}$ & $60 \mathrm{~V}$ & $67.8 \mathrm{~V}$ \\
Maximum $I_{D}$ & $9.8 \mathrm{~A}$ & $9.96 \mathrm{~A}$ \\
\hline
\end{tabular}
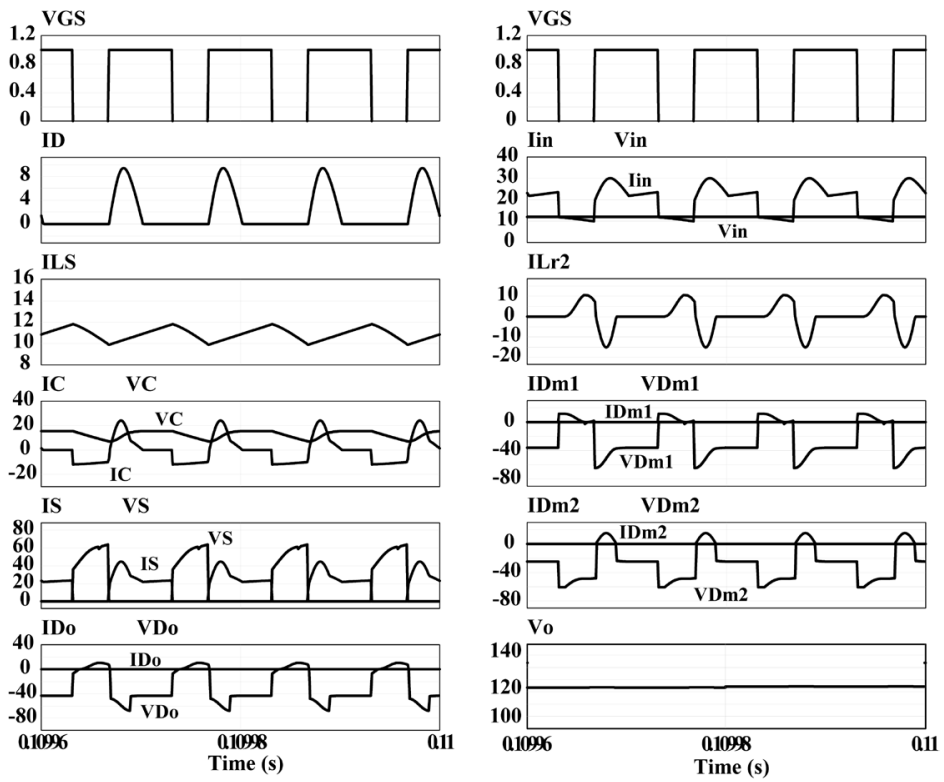

Figure 4. Simulated waveforms of the proposed converter.

the conventional boost converter, switched inductor boost converter (SIBC) [22] and voltage multiplier cell (VMC) based boost converter [19] for the same input and output specifications. The proposed converter has good voltage regulation compared to SIBC and VMC based converter. But the voltage regulation of the proposed converter and the conventional boost converter are almost same. The main drawbacks of the converter are that it has less efficiency and the voltage stress. But they can be improved by adopting the coupled inductor topology, by recycling the leakage energy in the inductors and by using resonant switching methods. 


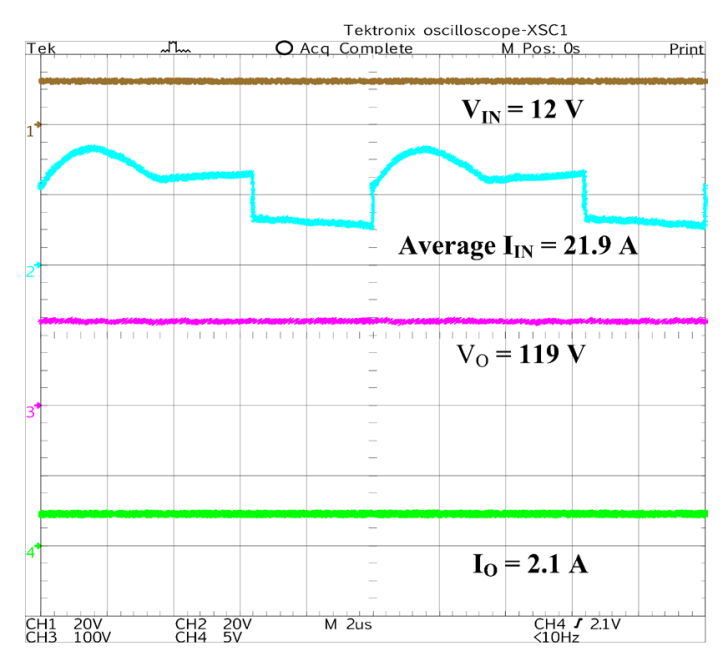

(a)

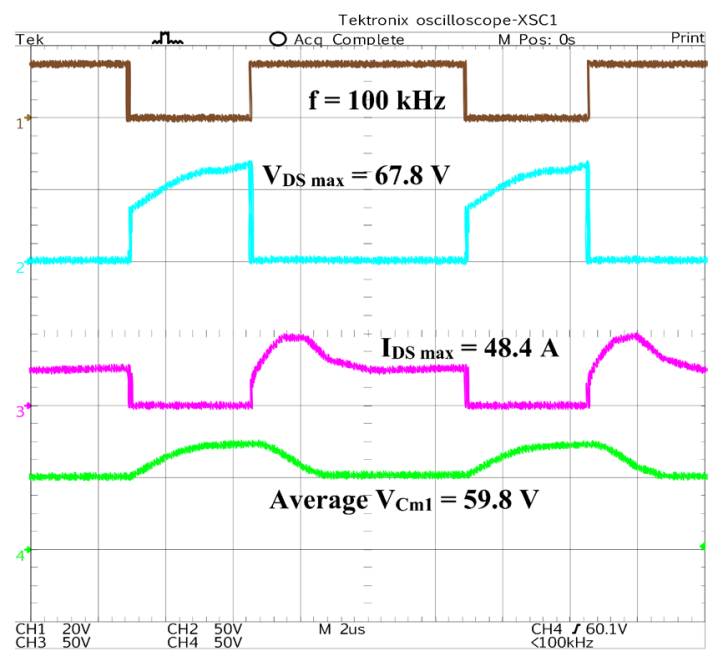

(b)

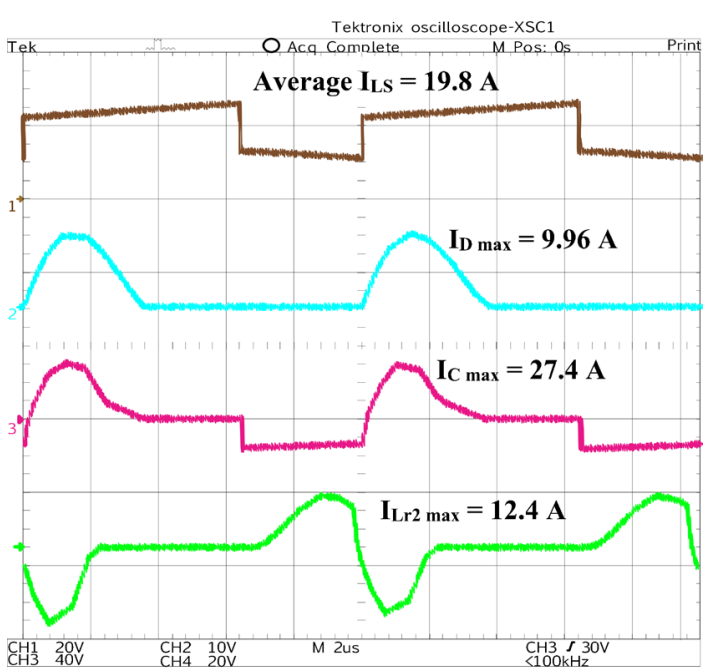

(c)

Figure 5. Experimental waveforms of the proposed converter.

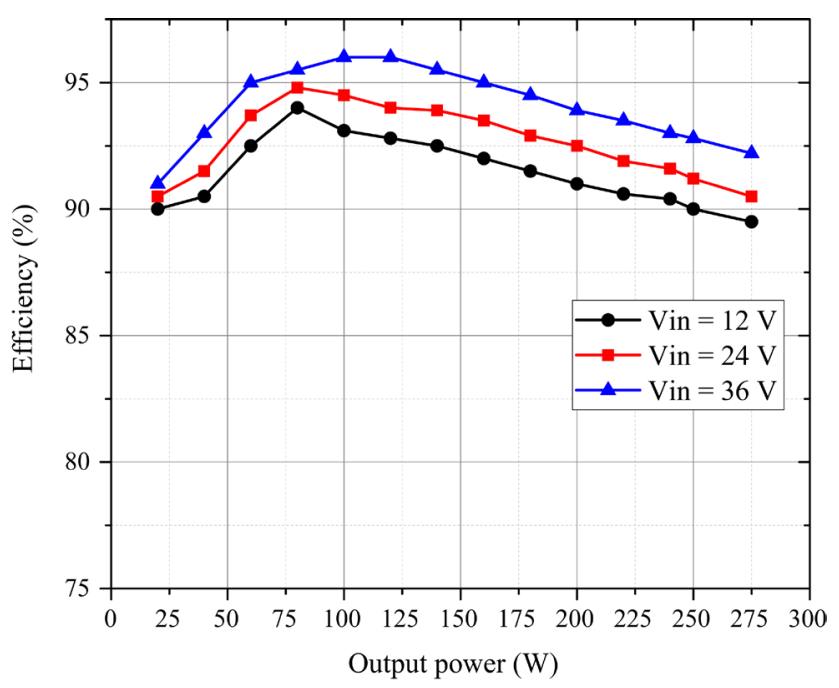

Figure 6. Experimental waveforms of the proposed converter. 


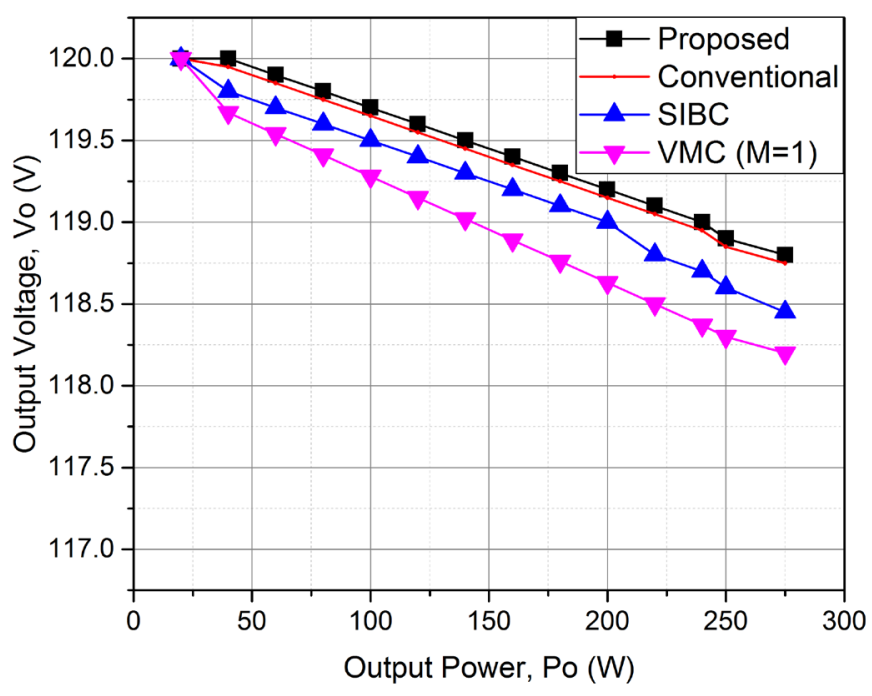

Figure 7. Experimental waveforms of the proposed converter.

\section{Conclusion}

In this paper, a high step-up boost converter has been designed by using switched diode inductor cell and a capacitor. The proposed converter is designed to use in unidirectional power transfer applications. The voltage multiplier is used to improve the step-up capability. The detailed steady state operation of the proposed converter is analyzed and simulated. Simulation results validate the theoretical analysis. The proposed converter can be designed by using devices with low voltage rating because the voltage stress across the power devices is low. A $250 \mathrm{~W}$ converter prototype was built and it is proven to be beneficial. Also the efficiency of the converter is above $90 \%$ and a maximum of $95 \%$. The main drawbacks of the proposed converter are that the efficiency and gain is low and it can be improved further by adopting soft switching technology, coupled inductor topology, recycling the leakage energy of the inductor. The proposed converter can also be used for industrial applications where high DC voltage is needed.

\section{References}

[1] Ramakumar, R. and Bigger, J.E. (1993) Photovoltaic systems. Proceedings of the IEEE, 81, 365-377. http://doi.org/10.1109/5.241491

[2] Carrasco, J.M., Franquelo, L.G., Bialasiewicz, J.T., Galvan, E., PortilloGuisado, R.C., Prats, M.A.M., Leon, J.I. and Moreno-Alfonso, N. (2006) Power-Electronic Systems for the Grid Integration of Renewable Energy Sources: A Survey. IEEE Transactions on Industrial Electronics, 53, 1002-1016. http://doi.org/10.1109/TIE.2006.878356

[3] Yang, L.-S., Liang, T.-J. and Chen, J.-F. (2009) Transformerless DC-DC Converters with High Step-Up Voltage Gain. IEEE Transactions on Industrial Electronics, 56, 3144-3152. http://doi.org/10.1109/TIE.2009.2022512

[4] Li, W., Fan, L., Zhao, Y., He, X., Xu, D. and Wu, B. (2012) High-Step-Up and High-Efficiency Fuel-Cell PowerGeneration System With Active-Clamp Flyback-Forward Converter. IEEE Transactions on Industrial Electronics, 59, 599-610. http://doi.org/10.1109/TIE.2011.2130499

[5] Lee, S., Kim, P. and Choi, S. (2013) High Step-Up Soft-Switched Converters Using Voltage Multiplier Cells. IEEE Transactions on Power Electronics, 28, 3379-3387. http://doi.org/10.1109/TPEL.2012.2227508

[6] Fu, J., Zhang, B., Qiu, D. and Xiao, W. (2014) A Novel Single-Switch Cascaded DC-DC Converter of Boost and Buck-Boost Converters. 16th European Conference on Power Electronics and Applications, Lappeenranta, 26-28 August 2014, 1-9. http://doi.org/10.1109/EPE.2014.6910723

[7] Liang, T.-J., Liang, H.-H., Chen, S.-M., Chen, J.-F. and Yang, L.-S. (2014) Analysis, Design, and Implementation of a Bidirectional Double-Boost DC-DC Converter. IEEE Transactions on Industry Applications, 50, 3955-3962. http://doi.org/10.1109/TIA.2014.2315504

[8] Park, K.-B., Moon, G.-W. and Youn, M.-J. (2011) Nonisolated High Step-Up Stacked Converter Based on BoostIntegrated Isolated Converter. IEEE Transactions on Power Electronics, 26, 577-587. http://doi.org/10.1109/TPEL.2010.2066578 
[9] Muller, L. and Kimball, J.W. (2014) Effects of Stray Inductance on Hard-Switched Switched Capacitor Converters. IEEE Transactions on Power Electronics, 29, 6276-6280. http://doi.org/10.1109/TPEL.2014.2332815

[10] Wu, G., Ruan, X. and Ye, Z. (2015) Nonisolated High Step-Up DC-DC Converters Adopting Switched-Capacitor Cell. IEEE Transactions on Industrial Electronics, 62, 383-393. http://doi.org/10.1109/TIE.2014.2327000

[11] Tang, Y., Fu, D., Wang, T. and Xu, Z. (2015) Hybrid Switched-Inductor Converters for High Step-Up Conversion. IEEE Transactions on Industrial Electronics, 62, 1480-1490. http://doi.org/10.1109/TIE.2014.2364797

[12] Zhang, X., Jiang, L., Deng, J., Li, S. and Chen, Z. (2014) Analysis and Design of a New Soft-Switching Boost Converter with a Coupled Inductor. IEEE Transactions on Power Electronics, 29, 4270-4277. http://doi.org/10.1109/TPEL.2013.2285708.

[13] Hsieh, Y.-P., Chen, J.-F., Yang, L.-S., Wu, C.-Y. and Liu, W.-S. (2014) High-Conversion-Ratio Bidirectional DC-DC Converter with Coupled Inductor. IEEE Transactions on Industrial Electronics, 61, 210-222. http://doi.org/10.1109/TIE.2013.2244541

[14] Liu, H.-C. and Li, F. (2015) Novel High Step-Up DC-DC Converter with an Active Coupled-Inductor Network for a Sustainable Energy System. IEEE Transactions on Power Electronics, 30, 6476-6482. http://doi.org/10.1109/TPEL.2015.2429651

[15] Hsieh, Y.-P., Chen, J.-F., Liang, T.-J. and Yang, L.-S. (2012) Novel High Step-Up DC-DC Converter with CoupledInductor and Switched-Capacitor Techniques. IEEE Transactions on Industrial Electronics, 59, 998-1007. http://doi.org/10.1109/TIE.2011.2151828

[16] Berkovich, Y., Beck, Y. and Axelrod, B. (2015) High Step-Up DC-DC Converter Based on the Switched-CoupledInductor Boost Converter and Diode-Capacitor Multiplier: Steady State and Dynamics. IET Power Electronics, 8, 1420-1428. http://doi.org/10.1049/iet-pel.2014.0785

[17] Chen, S.-M., Lao, M.-L., Hsieh, Y.-H., Liang, T.-J. and Chen, K.-H. (2015) A Novel Switched-Coupled-Inductor DCDC Step-Up Converter and Its Derivatives. IEEE Transactions on Industry Applications, 51, 309-314. http://doi.org/10.1109/TIA.2014.2332642

[18] Ajami, A., Ardi, H. and Farakhor, A. (2015) A Novel High Step-Up DC/DC Converter Based on Integrating Coupled Inductor and Switched-Capacitor Techniques for Renewable Energy Applications. IEEE Transactions on Power Electronics, 30, 4255-4263. http://doi.org/10.1109/TPEL.2014.2360495

[19] Prudente, M., Pfitscher, L.L., Emmendoerfer, G., Romaneli, E.F. and Gules, R. (2008) Voltage Multiplier Cells Applied to Non-Isolated DC-DC Converters. IEEE Transactions on Power Electronics, 23, 871-887. http://doi.org/10.1109/TPEL.2007.915762

[20] Li, W., Zhao, Y., Deng, Y. and He, X. (2010) Interleaved Converter with Voltage Multiplier Cell for High Step-Up and High-Efficiency Conversion. IEEE Transactions on Power Electronics, 25, 2397-2408. http://doi.org/10.1109/TPEL.2010.2048340

[21] Wu, B., Li, S., Liu, Y. and Ma Smedley, K. (2016) A New Hybrid Boosting Converter for Renewable Energy Applications. IEEE Transactions on Power Electronics, 31, 1203-1215. http://doi.org/10.1109/TPEL.2015.2420994

[22] Axelrod, B., Berkovich, Y. and Ioinovici, A. (2008) Switched-Capacitor/Switched-Inductor Structures for Getting Transformerless Hybrid DC-DC PWM Converters. IEE Transactions on Circuits and Systems I: Regular Papers, 55, 687-696. http://doi.org/10.1109/TCSI.2008.916403

[23] Hu, Y., Li, K., Yin, Z. and Ioinovici, A. (2015) Switched-Inductor-Based Non-Isolated Large Conversion Ratio, Low Components Count DC-DC Regulators. IEEE Energy Conversion Congress and Exposition (ECCE), Montreal, 20-24 September 2015, 1398-1405. http://doi.org/10.1109/ECCE.2015.7309856 